\title{
Structure and floristic survey of a forest fragment in the Billings Reservoir, São Paulo
}

The Atlantic Forest is the largest biome in the State of São Paulo, one of the most biodiverse ecosystems complexes on the planet, considered a conservation hotspot. This work aimed to list the plant species through the classification of the life forms of RAUNKIAER (1905), improved by CABRERA \& WILLINK (1973). The survey of the species was carried out by prospecting's in 54 quadratic plots of $36 \mathrm{~m}^{2}$, evenly distributed in a forest fragment of $48,010.91 \mathrm{~m}^{2}$. There recorded 97 species distributed in 47 families, with predominance Myrtaceae. The survey was carried out in December 2017, of the total number of species collected in the area of the fragment: 63 are trees, 17 are herbaceous, 6 are epiphytic, 4 are lianas, 3 are shrubs, 2 are palm trees, one is arborescent and one scandent. It is worth noting the registration of the vulnerable species Euterpe edulis, all botanical material is in the Herbarium RBR - UFRRJ - Institute of Biological and Health Sciences.

Palabras-chave: Biodiversity; Dense Ombrophilous Forest; Nature Conservation; Billings Reservoir.

\section{Estrutura e levantamento florístico de um fragmento de mata atlântica na Represa Billings, São Paulo}

\begin{abstract}
A Mata Atlântica é o maior bioma do Estado de São Paulo, um dos complexos ecossistêmicos mais biodiversos do planeta, considerado um hotspot para conservação. Este trabalho teve como objetivo listar as espécies vegetais através da classificação das formas de vida de RAUNKIAER (1905), aprimorada por CABRERA \& WILLINK (1973). O levantamento das espécies foi realizado por prospecções em 54 parcelas quadráticas de $36 \mathrm{~m}^{2}$, distribuídas uniformemente num fragmento florestal de $48.010 .91 \mathrm{~m}^{2}$. Foram registradas 97 espécies, distribuídas em 47 famílias, com predominância de Myrtaceae. 0 levantamento foi realizado em dezembro de 2017, do total de espécies levantadas na área do fragmento: 63 foram árvores, 17 ervas, 6 epífitas, 4 lianas, 3 arbustos, 2 palmeiras, 1 é arborescente e 1 é árvore escandente. Destaca-se o registro da espécie vulnerável Euterpe edulis, todo material botânico encontra-se Herbário RBR - UFRRJ Instituto de Ciências Biológicas e da Saúde.
\end{abstract}

Keywords: Biodiversidade; Floresta Ombrófila Densa; Conservação da Natureza; Represa Billings.

Topic: Uso de Recursos Naturais

Received: 23/06/2018

Approved: 13/08/2018

Reviewed anonymously in the process of blind peer.

Cleber Vinicius Vitorio Silva (iD

Fundação Oswaldo Cruz, Brasil

http://lattes.cnpq.br/4275890458575782

http://orcid.org/0000-0001-8337-9615

clebervitorio88@gmail.com

Josimar Ribeiro Almeida (iD)

Universidade do Estado do Rio de Janeiro, Brasil

http://lattes.cnpq.br/3215586187698472

http://orcid.org/0000-0001-5993-0665

almeida@poli.ufrj.br

Carlos Eduardo Silva (iD)

Universidade Tiradentes, Brasil

http://lattes.cnpq.br/3700554054159220

http://orcid.org/0000-0001-8358-0263

carlos.eduardo@cbpciencia.com.br

\author{
Lyanna Oliveira de Carvalho (iD) \\ Centro Universitário Estadual da Zona Oeste, Brasil \\ http://lattes.cnpq.br/1472384194462135 \\ http://orcid.org/0000-0003-0372-5114 \\ yannacarvalhoadaptada@gmail.com \\ Carlos Domingos da Silva (iD \\ Universidade Federal Rural do Rio de Janeiro, Brasil \\ http://lattes.cnpq.br/6460426372841261 \\ http://orcid.org/0000-0001-8976-3220 \\ cdambiental@gmail.com \\ Luccas Henrique Gomes Rigueiral \\ Universidade de Mogi das Cruzes \\ http://lattes.cnpq.br/7108743641214596 \\ http://orcid.org/0000-0001-5379-5669 \\ Irigueiral@hotmail.com
}

Raphael Gomes de Paula

Universidade Estácio de Sá

http://lattes.cnpq.br/9367829359889914

https://orcid.org/0000-0002-4410-6865

depaularaphael@hotmail.com

\section{Referencing this:}

SILVA, C. V. V.; ALMEIDA, J. R.; SILVA, C. E.; CARVALHO, L. O.; SILVA, C. D.; RIGUEIRAL, L. H. G.; PAULA, R. G.. Structure and floristic survey of a forest fragment in the Billings Reservoir, São Paulo. Revista lbero Americana de Ciências Ambientais, v.9, n.7, p.1-11, 2018. DOI: http://doi.org/10.6008/CBPC2179-6858.2018.007.0001 


\section{INTRODUCTION}

Approximately 54.4\% of Brazil's territory is occupied by forests (FLORESTAS DO BRASIL, 2015) and from this percentage, approximately $12.5 \%$ corresponds to the area of the Atlantic Rainforest Biome (SOS MATA ATLÂNTICA, 2015), stretching for 17 States of the federation, going from the state of Rio Grande do Sul to Rio Grande do Norte, ranging from the coastal regions, such as plateaus and hills of the interior.

In the state of São Paulo, the Atlantic Forest biome offers characteristic phytoecological formations constituted by forest ecosystems: Seasonal Semidecicual Forest and Dense Ombrophilous Forest. The latter features subdivisions in its phytophysiognomy, suffering variations according to the altitude range of relief where it is inserted. The divisions are: The Alluvial Lowlands, Submontane Forest, Montana and AltoMontana (SOS MATA ATLÂNTICA, 2015).

According to RODRIGUES et al. (2017), in addition to this important set of forest ecosystems, the Atlantic Forest also covers other associated ecosystems such as mangroves, restingas, mixed Araucarias forestry and the altitude fields.

The biome stretched by more than $90 \%$ of the total area of the state of São Paulo, according to the annual balance sheet presented by the non-governmental organization SOS Mata Atlântica (2015), until the end of the 1990's, approximately $15 \%$ of the area of this territory was still covered by native vegetation. The report of the institution demonstrates that the historical process of anthropic intervention has been happening since the discovery of Brazil and has been expanding over the centuries, due to some activities of economic development, such as exploitation of timber, agricultural and industrial activities. Another factor associated with the loss of vegetation is the unplanned urban growth, which in Brazil occurs mainly in areas that are covered by the biome (SOS MATA ATLÂNTICA, 2015).

According to INPE (2018), of the total Atlantic Forest, 23,548 hectar of vegetation were suppressed of which corresponds to $7 \%$ of its forest remains, safeguarded mainly in these areas of more difficult access, how to slopes of the Serra do Mar, considered unsuitable for agricultural practices. This territory has large forest spots adjacent to areas of high fragmentation (ARROMBA et al., 2012). The law n.11.428/2006 determines the area of protection of the biome for the 17 states of the federation, which corresponds to $38 \%$ of the Brazilian territory. Studies of the INPE (2018) point out that the whole area of Atlantic Forest had approximately $1,300,000 \mathrm{~km}^{2}$ of extension, and now is reduced to $162,666 \mathrm{~km}^{2}$, the equivalent to $12.4 \%$ of its original forest cover, as today has many uses, some of them being: the remaining forest, planted forests (mainly pinus and eucalyptus), pastures and agricultural crops of annual and perennial plants.

However, even facing an intense and historical process of deforestation, the Atlantic Forest biome has one of the largest biodiversity in the planet, with high concentrations of endemic species (BERGALLO et al., 2016) and a high level of degradation. Thus, it is possible to consider it as a hotspot, being the conservation of its natural resources of utmost importance to mankind.

This high biodiversity has been attributed to climate and geographical characteristics that vary greatly throughout its territory, which account for this biome's vegetation variations followed by a specific fauna and 
flora composition. It is estimated that over 1360 species of mammals, birds, reptiles, and amphibian occur in the biome. 567 of those are endemic. Superior plants total 20,000 species, more than half of the endemic mass.

The state of São Paulo is included in the Atlantic Forest domain. The devastation of forests in this state is happening almost since the period of its discovery, drastically reducing their original vegetation coverage. Only $7.26 \%$ of the original area remains (TAVARES et al., 2012; FUNDAÇÃO SOS MATA ATLÂNTICA et al., 2011), it is vital that the green areas and woody species that still exist are preserved. Especially considering the various services that the forest ecosystem can provide., such as: maintenance of water resources, conservation and preservation of soils and the concentration of atmospheric carbon in forest fragments.

The city São Bernardo do Campo is located at the top of the Serra do Mar, the Atlantic Plateau, however in almost every area of Atlantic Forest in the region, it is possible to observe influxes of eucalyptus and pine trees, the livestock and agriculture also distort the Atlantic Forest site, in addition to the massive synthesis of real estate ventures.

Billings reservoir is one of the biggest and most important reservoirs of water in the Metropolitan Region of São Paulo. The West borders the watershed of the Guarapiranga reservoir, and South, Serra do mar. Its main rivers and streams are the Rio Grande or Jurubatuba. Located in a fishing region with an emerging spot of strong environmental interest, its area of the original forest is altered, when not completely deleted due to the deployment of real estate ventures or agriculture, in addition to the cultivation of Pinus $s p .$, Eucalyptus sp. and Corymbia sp. For these reasons, even today, its humid areas of ecotone with rain forests and gallery forests, although quite affected by human activity, stand still as important floristic and faunistic elements of interest to conservationists, especially the flora (SOS MATA ATLÂNTICA, 2015).

Because of importance of the Billings reservoir for the state of São Paulo and the need for the preservation of its ecosystem, the objective of this work was to list the botanical species through the classification of the life forms of RAUNKIAER (1905) improved by CABRERA et al. (1973), through the installation of 54 plots (UA) of $36 \mathrm{~m}^{2}$ arranged randomly in a forest fragment of $48,010.91 \mathrm{~m}^{2}$ encompassing a sampling area of $1944 \mathrm{~m}^{2}$.

\section{MATERIAL AND METHODS}

\section{Characterization of the study area}

The forest fragment is in the area of influence of the Billings reservoir (Figure 1) in the municipality of São Bernardo do Campo, which is one of the largest and most important reservoirs of water in the Metropolitan Region of São Paulo.

The dam was conceived in the decades of 1930 and 1940 by engineer Billings, one of the employees of the former energy provider Light. Initially, the dam had the objective of storing water to generate electrical power for the hydroelectric plant Henry Borden in Cubatão. 
The city São Bernardo do Campo has a warm climate and temperate climate. There is significant rainfall throughout the year, even the driest month there is plenty of rainfall. According to the Köppen Geiger and the climate is classified as CFB (LUCHIARI et al., 2012). In São Bernardo do Campo, the average temperature is $17.8^{\circ} \mathrm{C}$, the average annual rainfall is $1524 \mathrm{~mm}$. The difference between the precipitation of the driest month and the rainiest is $190 \mathrm{~mm}$. Throughout the year the average temperatures vary $6.5^{\circ} \mathrm{C}$. The hottest month of the year is February with an average temperature of $20.9^{\circ} \mathrm{C}$. July has an average temperature of $14.4^{\circ} \mathrm{C}$, this was the lowest mean temperature, precipitation in the month of July is $44 \mathrm{~mm}$, this being the driest month. The wettest month was January, with an average of $234 \mathrm{~mm}$.

The forest fragment located in the Taquacetuba Road, in the Taquacetuba neighborhood, under the inscription 624700708000, in the Alto-Tietê's basin area, specifically in the sub-basin of the Billings reservoir. The main access roads to the location of the project are by the highway of Imigrantes and by Mário Covas Beltway, so it is in an important and privileged geographical position. In accordance with the environmental process N 59.602/2017, the fragment has 3 stages of succession: initial, medium and advanced, the largest portion of the successional stage corresponding to the 'initial' stage.

\section{Sample Design and Analysis}

From 10 December until 23 December 2017, 54 square (6x6 m) sampling units were systematically demarcated in the area of the real state interest, total of $1944 \mathrm{~m}^{2}$ of sampling area (figure 1) the fragment studied has a total area of $48,010,91 \mathrm{~m}^{2}$, the field team mapped all the botanic species occurring in the 36 $\mathrm{m}^{2}$ units, RAUNKIAER's classification of life forms (1905), refined by Cabrera et al. (1973). Within each quadratic plot they were collected arboreal species with CAP greater than or equal to $5 \mathrm{~cm}$ and estimated the height and the radius of the canopy of sampled individuals. The quadrats were marked with striped tape. The vertex closest to the access to the sampling unit was georeferenced using a GPS with an accuracy of 3 meters under vegetation cover, as well as the horizontal and vertical structure of the tree community and the basal area of all plots, besides to include all life forms like herbs, vines, palms, trees, arborescens, shrubs, creepers and scandalized trees. The material was studied and duly deposited in Herbarium Herbarium RBR UFRRJ - Institute of Biological and Health Sciences. The results obtained in this study were paired with Resolution n.01/1994 of the Environment National Council (CONAMA).

The simple random sampling is the fundamental process of selection from which to derive all other sampling procedures, aiming to increase the accuracy of estimates and to reduce the costs of the survey (RIBEIRO et al., 2009).

The simple random sampling is the best method for presentation of the theory of sampling, because it allows estimating the sampling error. The selection of each sampling unit must be free of any choice and totally independent from the selection of the other sample units. The equation for the calculation of the sample sufficiency in simple random sampling is shown below (HUSCH et al.1982) (Equation 1):

$$
n=N \times S^{2} \times t^{2} /\left(N \times\left(E x x^{-}\right)^{2}+S^{2} \times t^{2}(1)\right.
$$


Where:

$\mathbf{n}=$ number of parcels to be raised;

$\mathbf{N}=$ total number of samples possible in the area; $\mathbf{t}=$ value of probability distribution ( $\mathrm{t}_{0.10}$, with $\left.\mathrm{n}-1 \mathrm{GL}\right)$; $\mathbf{S}^{2}=$ variance of the parameter evaluated; $\mathbf{x}^{-}=$average $\mathbf{E}=$ Error $(10 \%)$ and $\mathbf{X}=$ Average of the parameter evaluated.

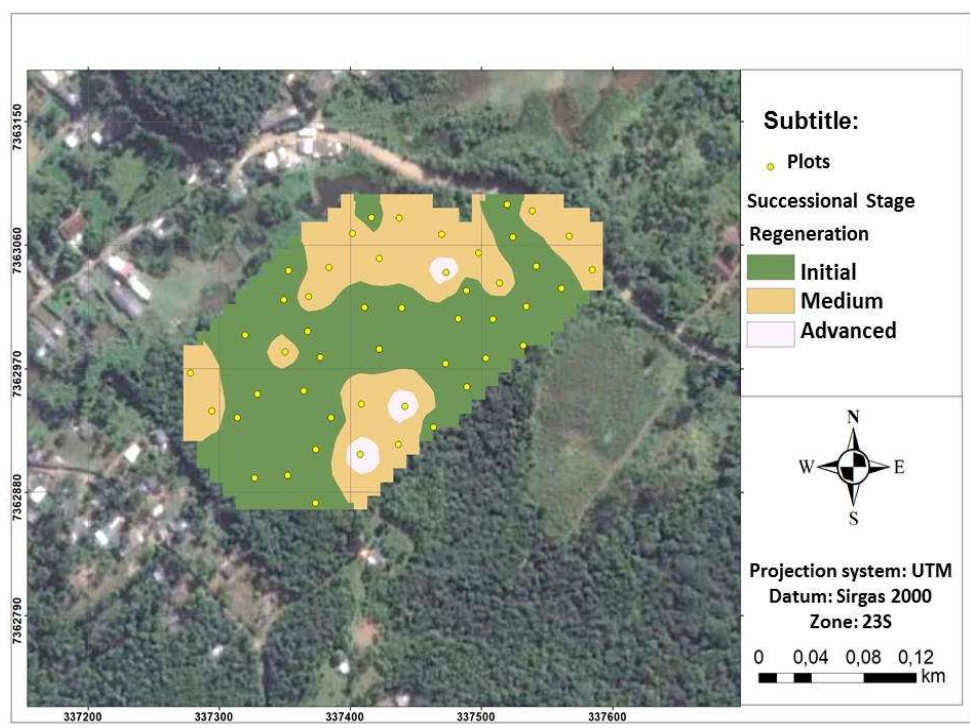

Figure 1: Classification of successional stage of regeneration of the fragment and provision of sample units in the area of studies. Total area: 48,010.91 $\mathrm{m}^{2}$.

\section{RESULTS AND DISCUSSIONS}

For the calculation of the sample sufficiency in simple random sampling, met a $n=45.65$ sample units (U.A) for the total area of 48,010.91 $\mathrm{m}^{2}$ ( $\mathrm{N}=54 ; \mathrm{S} 2=24.40531 ; \mathrm{S}=4.94$ plants; Std. Error= 0.67 plants; $\mathrm{CV}=$ $42.89 \%$; an estimate of the total population= 57.613092; $\mathrm{Cl}=12 \pm 1.12$ plants per hectare), so the allocation of 54 plots of $36 \mathrm{~m}^{2}$ was sampled more than representative for this work, it can be concluded that the sampling was sufficient.

The field team listed 97 species belonging to 47 families (Table 1), where Myrtaceae was the most abundant family with 9 species, all of which were trees, followed by Lauraceae and Rubiaceae families with 6 species, Melastomataceae and Poaceae with 5 species each.

Table 1: List of the floristic composition of Families and Species sample in the prospection, Represa Billings-SP $\mathrm{Hab}=$ habit, $\mathrm{AR}=$ trees, $\mathrm{AB}=$ =bushes, $\mathrm{HE}=$ herbaceous, $\mathrm{PA}=$ palm trees, $\mathrm{LI}=$ lianas, $\mathrm{ABR}=$ arborescent and $\mathrm{ABE}=\mathrm{scandent}$ tree. $\mathrm{SD}=$ dispersion syndrome: Zoo=zoochorous, Anemo=anemoric, Auto=autochoric; Hidro=hydrochoric. SC=No classification. Suce=Successional Stage $\mathrm{P}=$ pioneer; $\mathrm{NP}=$ non-pioneer.

\begin{tabular}{|c|c|c|c|c|c|c|c|}
\hline $\mathbf{N}$ & Family & Vernacular & Taxon & Origin & SD & Suce & Hábit \\
\hline 1 & Amaranthaceae & carrapicho & Achyranthes aspera & Native & Zoo & SC & $\mathrm{HE}$ \\
\hline 2 & Anacardiaceae & aroeira & Schinus terebinthifolia & Native & Zoo & $\mathrm{P}$ & AV \\
\hline 3 & Annonaceae & Araticum-de-tolo & Annona sp. & Native & Zoo & $\mathrm{P}$ & AV \\
\hline 4 & Annonaceae & envira & Guatteria australis & Native & Zoo & NP & AV \\
\hline 5 & Apiaceae & erva-doce & Foeniculum sp. & Exotic & Ane & & $\mathrm{HE}$ \\
\hline 6 & Areceaceae & Juçara & Euterpe edulis & Native & Zoo & NP & PA \\
\hline 7 & Areceaceae & Jerivá & Syagrus romanzoffiana & Native & Zoo & NP & PA \\
\hline 8 & Aspleniaceae & erva-epífita & Asplenium sp. & Native & Ane & SC & EP \\
\hline 9 & Asteraceae & assa peixe & Baccharis oreophila & Native & Ane & $P$ & $A B$ \\
\hline 10 & Asteraceae & cambara & Gochnatia polymorpha & Native & Ane & $\mathrm{P}$ & AV \\
\hline 11 & Asteraceae & vassourão & Piptocarpha axillaris & Native & Ane & $\mathrm{P}$ & AV \\
\hline
\end{tabular}


Asteraceae Bignoniaceae Bignoniaceae Blechnaceae Blechnaceae Bromeliaceae Bromeliaceae Bromeliaceae Bromeliaceae Cannabaceae

Celastraceae

Clethraceae

Clusiaceae

Cucurbitaceae

Cyatheaceae

Euphorbiaceae

Euphorbiaceae

Euphorbiaceae

Euphorbiaceae

Fabaceae

Fabaceae

Heliconiaceae

Lauraceae

Lauraceae

Lauraceae

Lauraceae

Lauraceae

Lauraceae

Marantaceae

Melastomataceae

Melastomataceae

Melastomataceae

Melastomataceae

Melastomataceae

Meliaceae

Meliaceae

Moraceae

Myrsinaceae

Myrsinaceae

Myrsinaceae

Myrsinaceae

Myrtaceae

Myrtaceae

Myrtaceae

Myrtaceae

Myrtaceae

Myrtaceae

Myrtaceae

Myrtaceae

Myrtaceae

Nyctaginaceae

Olacaceae

Orchidaceae

Orchidaceae

Pandanaceae

Passifloraceae

Peraceae

Pinaceae

Piperaceae

Poaceae

Poaceae

Poaceae

Poaceae

Poaceae

Polygonaceae

Polypodiaceae

Rosacae

vassourão branco
caroba
ipê-cinco-chagas
Samambaia
erva-terrícola
Quesnelia
caraguatá-do-campo
Tillandsia
Bromélia
Crandiúva
Maytenus
Aleixo
Clusia

Melão-de-São-Caetano

Samambaia açu Tapia

tapiazinho

Leiteira vermelha Mandioca

Angico Branco jequitiri heliconia

Canela sem cheiro

canela amarela

Canela comida

canela piper

canela fedorenta

canela de cheiro Maranta

pixirico amarelo miconia pixirico

pixirico rajado

manaca da serra canjerana

carrapeta

ficus elastica

capororoca grande

capororoca

capororoca-vermelha capororoca-vermelha Eucalipto

Goiabeira do mato

Cambuci s/ cheiro Pitanga

myrcia myrcia

myrcia murici

Myrcia splendens

Araça vermelho joao mole

ameixa-amarela

orquídea-amarela

micro-orquídea

palmerinha-terrícola

maracujá-de-paca

$$
\text { Pera }
$$

Pinus

piper

colonião

capim

braquiária

grama-batatais

bambu

$$
\text { cocoloba }
$$

cipó cabeludo

Morango-silvestre

Piptocarpha sp.
Jacaranda puberula
Sparattosperma leucanthum
Telmatoblechnum sp.
Blechnum sp.
Quesnelia quesneliana
Bromelia antiacantha
Tillandsia sp.
Vriesea sp.
Trema micrantha
Maytenus sp.

Ane

P $\quad A V$

Native Ane NP AV

Native Ane $P$ EP

Native Hidro SC HE

Native Ane SC HE

Native Zoo SC HE

Native Zoo SC HE

Native Zoo SC EP

Native Ane NP EP

Native Zoo P AV

Native Zoo NP AV

Native Zoo P AV

Clethra scabra Pers.

Clusia criuva

Cucumis argyi

Cyathea cf. corcovadensis

Alchornea sp.

Alchornea triplinervia

Sapium glandulosum

Manihot esculenta

Pseudopiptadenia sp.

Abrus precatorius

Heliconia sp.

Endlicheria sp.

Nectandra grandiflora

Nectandra sp.

Nectandra sp2.

Ocotea aff. nitida

Ocotea odorifera

Ctenanthe sp.

Miconia cinnamomifolia

Miconia cubatanensis

Miconia fasciculata

Miconia sp.

Tibouchina mutabilis

Cabralea canjerana

Guarea macrophylla

ficus elastica

Myrsine aff. balansae

Myrsine coriacea

Myrsine gardneriana

Myrsine umbellata

Eucaliptus sp

Eugenia of glazioviana

Eugenia pruniformis

Eugenia uniflora

Myrcia multiflora

Myrcia sp.

Myrcia sp2.

Myrcia splendens

Psidium cattleianum

Guapira opposita

Ximenia americana

Alatiglossum longipes

Capanemia micromera

Freycinetia sp.

Passiflora sp.

Pera glabrata

Pinus sp.

Piper aduncum

Panicum maximum

Eragrostis sp.

Brachiaria decumbens

Paspalum notatum

Bambusa vulgaris

Coccoloba glaziovii

Polypodium sp.

Fragaria vesca

$\begin{array}{cccc}\text { Native } & \text { Zoo } & \text { P } & \text { AV } \\ \text { Native } & \text { Zoo } & \text { SC } & \text { LI }\end{array}$

Native Hidro NP ABR

Native Zoo $P$ AV

Native Zoo P AV

Native Zoo $P$ AV

Native Zoo $P$ AB

Native Auto NP AV

Native Zoo NP LI

Native Auto NP HE

Native Zoo NP AV

Native Zoo NP AV

Native Zoo NP AV

Native Zoo NP AV

Native Zoo NP AV

Native Zoo NP AV

Native Auto SC HE

Native Zoo $P$ AV

Native Zoo P AV

Native Zoo NP AV

Native Zoo $P$ AV

Native Auto P AV

Native Zoo NP AV

Native Zoo NP AV

Exotic Zoo SC AV

Native Zoo P AV

Native Zoo $P$ AV 


$\begin{array}{lc}\begin{array}{l}\text { Rubiaceae } \\ \text { Rubiaceae } \\ \text { Rubiaceae } \\ \text { Rubiaceae } \\ \text { Rubiaceae }\end{array} & \begin{array}{c}\text { café-preto } \\ \text { goiaba-do-mato } \\ \text { Café-taturana } \\ \text { Rubiaceae }\end{array} \\ \text { Rutaceae } & \text { Café liso } \\ \text { Rutaceae } & \text { cafézinho-do-mato } \\ \text { Salicaceae } & \text { falsa-aroeira } \\ \text { Sapindaceae } & \text { mamica-de-porca } \\ \text { Sapindaceae } & \text { Pau-lagarto } \\ \text { Sapindaceae } & \text { Camboata } \\ \text { Sapindaceae } & \text { Miguel-pintado } \\ \text { Sapotaceae } & \text { Cheiro-de-barata } \\ \text { Solanaceae } & \text { Correiro } \\ \text { Solanaceae } & \text { abiu-do-mato } \\ \text { Styracaceae } & \text { arrebenta-cavalo } \\ \text { Urticaceae } & \text { Tomate-do-mato } \\ \text { Verbenaceae } & \text { Benjoeiro } \\ & \text { Embaúba vermelha } \\ & \text { Camará }\end{array}$

Faramea tetragona
Psidium sp.
Psychotria sp.
Psychotria suterella
Psychotria vellosiana
Bathysa gymnocarpa
Zanthoxylum fagara
Zanthoxylum rhoifolium
Casearia sylvestris
Cupania oblongifolia
Matayba intermedia
Toulicia laevigata
Diatenopteryx sp.
Pouteria sp.
Solanum palinacanthum
Solanum sp.
Styrax lancifolius
Cecropia glaziovii
Lantana camara

$\begin{array}{lccc}\text { Native } & \text { Zoo } & \text { NP } & \text { AV } \\ \text { Native } & \text { Zoo } & \text { NP } & \text { AV } \\ \text { Native } & \text { Zoo } & \text { NP } & \text { AV } \\ \text { Native } & \text { Zoo } & \text { NP } & \text { AV } \\ \text { Native } & \text { Zoo } & \text { NP } & \text { AV } \\ \text { Native } & \text { Zoo } & \text { NP } & \text { AV } \\ \text { Native } & \text { Zoo } & \text { NP } & \text { AV } \\ \text { Native } & \text { Zoo } & \text { NP } & \text { AV } \\ \text { Native } & \text { Zoo } & \text { P } & \text { AV } \\ \text { Native } & \text { Zoo } & \text { NP } & \text { AV } \\ \text { Native } & \text { Zoo } & \text { NP } & \text { AV } \\ \text { Native } & \text { Ane } & \text { NP } & \text { AV } \\ \text { Native } & \text { Ane } & \text { P } & \text { AV } \\ \text { Native } & \text { Zoo } & \text { P } & \text { AV } \\ \text { Native } & \text { Zoo } & \text { SC } & \text { HE } \\ \text { Native } & \text { Zoo } & \text { SC } & \text { HE } \\ \text { Native } & \text { Zoo } & \text { NP } & \text { AV } \\ \text { Native } & \text { Zoo } & \text { P } & \text { AV } \\ \text { Native } & \text { Zoo } & \text { P } & \text { HE }\end{array}$

Of the total number of species mapped in the area of the project 63 are trees, 17 are herbaceous, 6 are epiphytic, 4 are lianas, 3 are shrubs, 2 are palm trees, one is arborescent and one scandent.

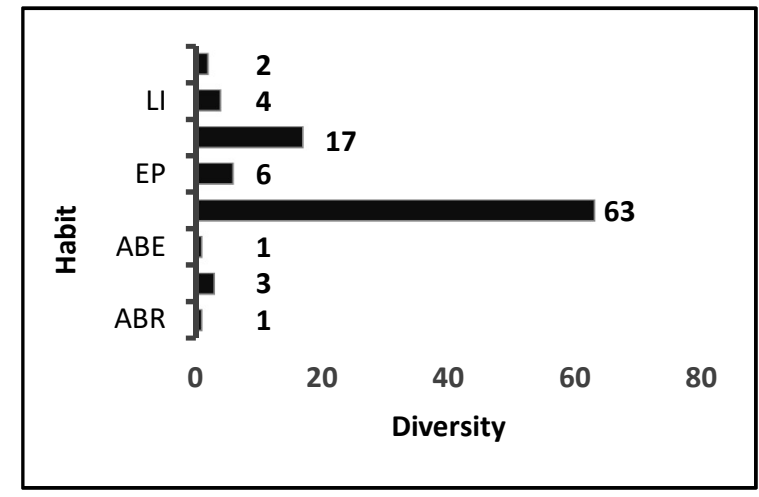

Figure 2: Habit of species mapped by Raunkiaer's Classification of Life Forms. Hab=habit: $A R=$ trees, $A B=$ bushes, $\mathrm{HE}=$ herbaceous, $\mathrm{PA}=$ palm tree, $\mathrm{LI}=$ lianas; $A B R=$ arborescent and $A B E=$ scadent trees. Source: by the author himself.

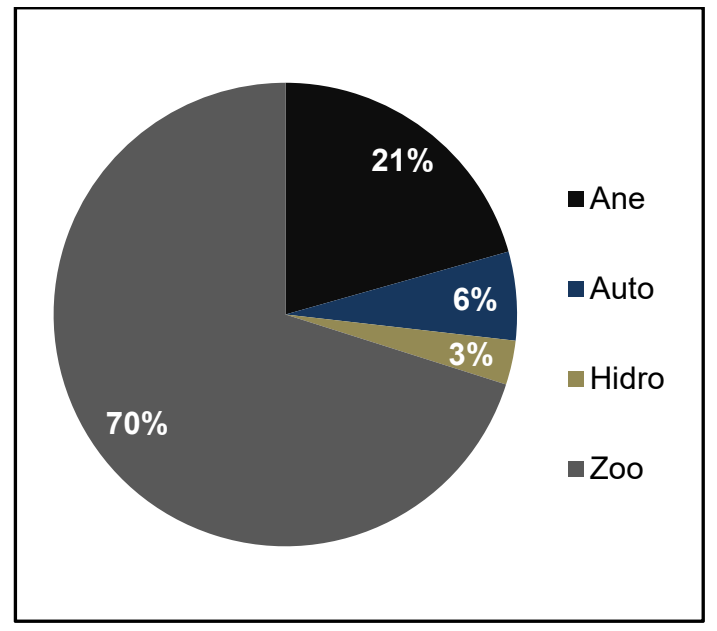

Figure 3: The dispersive syndrome of the forest ecosystem. Source: by the author himself.

From the 97 species mapped, 70\% present zoochoric dispersive syndrome, $21 \%$ anemochoric, 6\% autochoric, and 3\% hydrochoric. As for the Atlantic Forest These are paralel data from Silva, 2016 \& Silva, 2013 (Figure 2). Thus, demonstrating a strong association that the sampled ecosystem has the fauna, particularly the birds, and bats, two groups with the highest dispersive potential among the forestry species. The families Myrtaceae, Fabaceae, Rubiaceae and Sapotaceae, are examples of families that have strong relation with the animals from Atlantic Forest biome (SILVA, 2017).

Of the 97 species, $42 \%$ are classified as non pioneer, $31 \%$ are pioneers and $27 \%$ do not have successional classification (Figure 4), demonstrating is an area that has already been decharacterized in the past, now the fragment is in the process of ecological succession, with in different successional stages, as seen in Figure 4. 


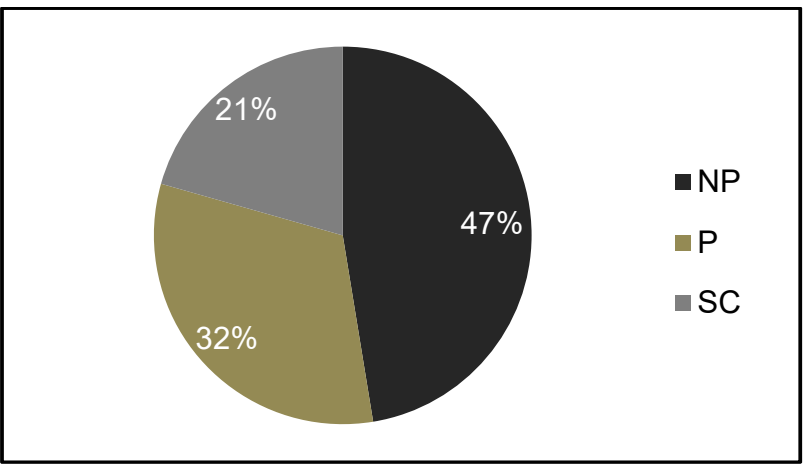

Figure 4: Successional Stage of the species mapped. Suce=Successional Stage $\mathrm{P}=$ pioneer; NP= non-pioneer and SC=no classification. Source: by the author himself.

The species Nectandra grandiflora, Ocotea aff. nitida, Ocotea odorifera, are Lauraceae associated with well-preserved forests (KROPF, 2006), and Euterpe edulis is a perennial, of shadow, mesophilic or slightly hydrophilic species (LORENZI, 2014). Among the pteridophytes, is the Cyathea cf. corcovadensis, which visually constitutes one of the major floristic components of the forest formations of Billings reservoir. The epiphytes Capanemia micromera and Alatiglossum longipes are indicative of ombrophilous environments with high humidity, zones characteristic of climactic forests (BUZATTO et al., 2010). The species: Myrsine aff. balansae, Myersine gardneriana, Myrsine coriacea and Myrsine umbellate, are considered habitat generalists by MARQUES et al. (2003), but are still widely found in surveys made for flooded forests of the Atlantic Forest and are widely distributed in the flooded areas sampled in this study, well as Pera glabrata, which is also generalist but widely found in surveys made for flooded forests.

One of the most striking elements of the landscape for the arboreal stratum was the abundance of the species of the genus Miconia and the species Tibouchina mutabilis, these taxa of the family Melastomataceae are pioneer species and characteristic of the wet slopes of the Serra do Mar. They tolerate very sunny locations and are more frequently found in the secondary vegetation of the Atlantic forest of the $A B C$ region of São Paulo.

Most of the survey species can still be described as of ethnobotanical importance, both for medicinal and ritualistic use of traditional communities, stand out the species for medical use, Cecropia glaziovii, Passiflora sp. and Schinus terebinthifolia, or for human consumption such as Myrtaceae of the genus Eugenia and Psidium and for Sapotaceae, Pouteria sp., corroborating with the floristic surveys in the Atlantic Forest for ethnobotanical purposes (JESUS, 1997).

For areas of advanced regeneration stage, were found important seedling banks and seeds of the species: Eugenia cf glazioviana, Eugenia pruniformis, Eugenia uniflora, Euterpe edulis, Quesnelia sp., Bromelia antiacantha, Tillandsia sp., Vriesea sp., Alatiglossum longipes e Capanemia micromera, due to its relation with the fauna in the establishment of a homeostasis.

The estimates of botanical diversity were similar to other botanical inventory studies in the Atlantic Forest, SILVA et al. (2012) found a diversity of 90 species belonging to 45 families in Mata Santa Genoveva in Presidente Prudente-SP and TAVARES et al. (2013) in one a survey synthesized in Ilha Grande-RJ, also raised the families Myrtaceae, Fabaceae and Rubiaceae as the most representative of the study. 
The heights of the trees measured in the inventory were distributed in three (3) classes with amplitude of stratum: lower, middle and upper. Distributed in accordance with Resolution N ${ }^{\circ}$ 01/1994 of the Environment National Council (CONAMA), in which the lower strata concentrated trees with up to $5.2 \mathrm{~m}$, the middle stratum of trees that had the height exceeding $5.2 \mathrm{~m}$ until the height of $14.5 \mathrm{~m}$ and the upper stratum of trees with height greater than 14.5 m. According to Martins, 1991, estimates of the heights of individuals shrubs and trees can provide important information for both the interpretation of vertical structure of the forest as an aid in understanding the dynamics of populations that compose it. According to the analysis of estimated heights of 553 trees (Figure 5), 202 are in the lower strata $(<5.2 \mathrm{~m}), 393$ are in the middle stratum $(>5.2$ and $<14.5 \mathrm{~m})$ and 27 are located on the upper stratum $(>14.5 \mathrm{~m})$, indicating an environment of regeneration and with recruitment of new individuals in each stratum of the forest ecosystem.

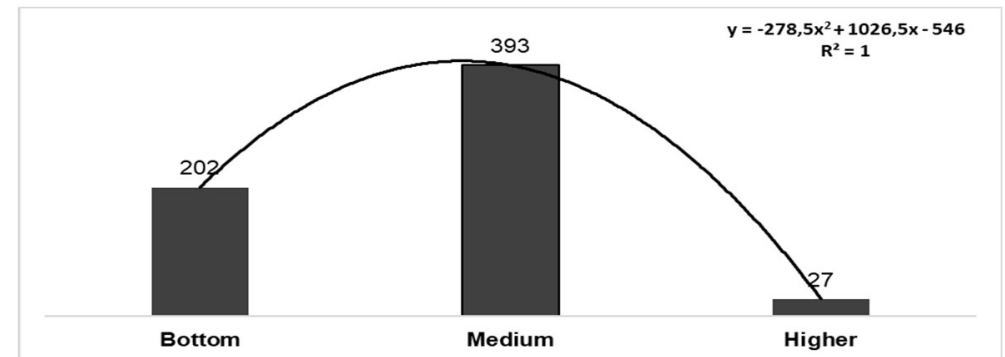

Figure 5: The vertical structure of the forest ecosystem. Source: by the author himself.

From the diametric structure drafted, it was found that the community forestry (Figure 6) showed a tendency to a J-inverted, that is, the higher number of individuals found in the smallest diameter classes, which is a typical behavior of multianeforests (SILVA et al., 2017).

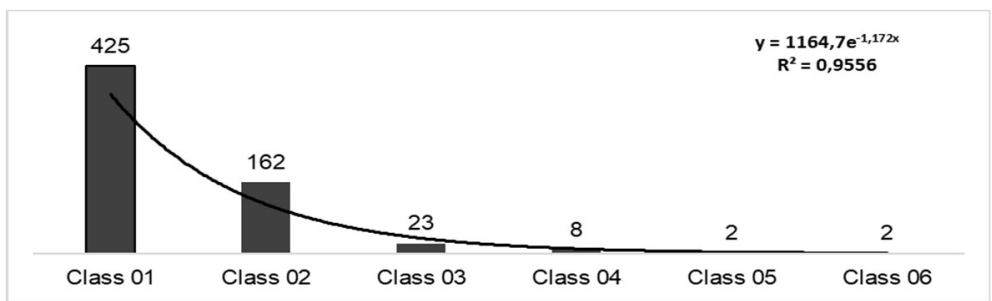

Figure 6: Distribution of frequency per class of Dbh of trees measured. Source: by the author himself.

The population parameters of mature forest (Table 3), in turn, are in accordance with the submitted in Resolution N ${ }^{\circ}$ 01/1994 of the Environment National Council (CONAMA), for forests in the initial stages and medium.

Table 2: Mean values $(\mathrm{X})$ of the variables measured by plot and successional stage of each plot analyzed. Legend: $\mathrm{G}(\mathrm{m} 2)$ - basal area; DAP $(\mathrm{cm})$ diameter of breast height; R.C $(\mathrm{m})$-radius of cup.

\begin{tabular}{cccccc}
\hline Parcels & $\mathrm{G}\left(\mathrm{m}^{2}\right)$ & $\mathrm{DAP}(\mathrm{cm})$ & stature $(\mathrm{m})$ & $\mathrm{R} . \mathrm{C}(\mathrm{m})$ & Phase \\
\hline 1 & 0.006094 & 8.57 & 5.56 & 2.13 & Page \\
3 & 0.007514 & 9 & 6.74 & 1.35 & Page \\
4 & 0.015629 & 11.33 & 6.4 & 1.75 & Average \\
5 & 0.013122 & 11.46 & 3.5 & 0.83 & Average \\
6 & 0.014691 & 12.46 & 7.91 & 1.75 & Average \\
7 & 0.0057 & 8.07 & 5.5 & 1.09 & Page \\
8 & 0.007127 & 8.84 & 4.89 & 1.07 & Page \\
9 & 0.048863 & 19.91 & 9.5 & 2.41 & Average
\end{tabular}




\begin{tabular}{|c|c|c|c|c|c|}
\hline 10 & 0.025425 & 17.19 & 10 & 2.33 & Average \\
\hline 11 & 0.003673 & 6.57 & 4.3 & 0.83 & Page \\
\hline 12 & 0.005511 & 8.11 & 4.5 & 1.65 & Page \\
\hline 13 & 0.009618 & 10.4 & 8.16 & 2.41 & Average \\
\hline 14 & 0.02677 & 18.46 & 8.5 & 2.6 & Average \\
\hline 15 & 0.006019 & 8.28 & 6.28 & 1.46 & Page \\
\hline 16 & 0.005109 & 7.76 & 5.38 & 1.66 & Page \\
\hline 17 & 0.003288 & 6.37 & 4.69 & 1.64 & Page \\
\hline 18 & 0.003858 & 6.71 & 9.15 & 2.02 & Page \\
\hline 19 & 0.038141 & 21.64 & 10.5 & 2.25 & Advanced \\
\hline 20 & 0.006118 & 8.09 & 5.87 & 1.97 & Page \\
\hline 21 & 0.019908 & 15.6 & 9.5 & 3.33 & Average \\
\hline 22 & 0.041097 & 17.26 & 11.58 & 2.44 & Average \\
\hline 23 & 0.008535 & 9.55 & 6.4 & 1.84 & Page \\
\hline 24 & 0.02981 & 18.67 & 10 & 2.84 & Average \\
\hline 25 & 0.00473 & 7.38 & 5.17 & 1.32 & Page \\
\hline 26 & 0.004635 & 7.48 & 10 & 1.25 & Page \\
\hline 27 & 0.004652 & 7.4 & 6.92 & 1.8 & Page \\
\hline 28 & 0.018239 & 8.7 & 2.4 & 0 & Page \\
\hline 29 & 0.008387 & 9.99 & 7.43 & 1.58 & Page \\
\hline 30 & 0.014019 & 12.73 & 6.35 & 2.37 & Average \\
\hline 32 & 0.012758 & 11.94 & 11.06 & 2.75 & Average \\
\hline 33 & 0.004584 & 7.63 & 6.5 & 1.8 & Page \\
\hline 34 & 0.006828 & 8.91 & 4 & 0.76 & Page \\
\hline 36 & 0.055993 & 23.44 & 9.16 & 4.5 & Advanced \\
\hline 37 & 0.022707 & 12.89 & 7.75 & 1.54 & Average \\
\hline 38 & 0.010021 & 10.42 & 9.75 & 2.13 & Average \\
\hline 40 & 0.007009 & 9 & 4.5 & 0.94 & Page \\
\hline 41 & 0.01204 & 8.75 & 7.25 & 1.5 & Page \\
\hline 42 & 0.031143 & 15.69 & 8.79 & 2.53 & Average \\
\hline 43 & 0.000897 & 9.44 & 5.87 & 2.26 & Page \\
\hline 44 & 0.007993 & 8.36 & 6.84 & 2.25 & Page \\
\hline 45 & 0.008666 & 9.16 & 6.89 & 1.99 & Page \\
\hline 46 & 0.003858 & 6.74 & 5.81 & 1.3 & Page \\
\hline 47 & 0.00391 & 6.96 & 6.38 & 1.67 & Page \\
\hline 48 & 0.006005 & 8.3 & 5.32 & 1.21 & Page \\
\hline 49 & 0.003716 & 6.61 & 3.78 & 0.86 & Page \\
\hline 50 & 0.053702 & 20.9 & 8.4 & 2.3 & Advanced \\
\hline 51 & 0.006878 & 9.03 & 6.08 & 1 & Page \\
\hline 60 & 0.007095 & 9.23 & 4.92 & 1.35 & Page \\
\hline 61 & 0.009028 & 9.07 & 7.35 & 1.9 & Page \\
\hline 71 & 0.009691 & 10.66 & 7.5 & 1.67 & Average \\
\hline 72 & 0.000322 & 10.9 & 6.78 & 1.7 & Average \\
\hline 77 & 0.005231 & 7.98 & 3.67 & 1.3 & Page \\
\hline
\end{tabular}

Only the species Euterpe edulis is vulnerable according to the red book of the Brazilian flora, the species has been suffering from its illegal extraction in the areas of Atlantic Forest, where it is endemic, is a slow-growing palm that is unable to regrow (MARTINELLI et al., 2013).

\section{CONCLUSIONS}

The results presented are important contributions in the knowledge of the plant species richness of the Billings Reservoir sub-basin, providing secondary data for subsequent environmental studies aiming at this same region.

The Dense Ombrophylous Forest fragment studied, despite suffering the consequences of the anthropomorphism of the landscape, presents at present a high number of species and a good diversity when compared to other forest fragments of the Atlantic Forest Biome. 
The Atlantic Forest is a biodiversity hotspot, forest restoration actions must be carried out in their ecosystems, because it is a priority biome for conservation and environmental preservation. The recovery of their areas is essential for the quality of life of the communities, considering the amount of environmental services that the ecologically balanced environment can offer. Environmental education actions must be taken by the public authority with the purpose of alleviating the current dumping of waste in the fragments of the Billings reservoir, that is, with the purpose of promoting actions for the conservation of biodiversity.

\section{REFERENCES}

ARROMBA, A. L.; LEONEL, C.; SANTIAGO, C. de M.; MAZZEI K.; BUCCI, L. A.; NALON, M.A.; BARROS, M. I. A.. Plano de Manejo do Parque Estadual Alberto Löfgren. São Paulo: Instituto Florestal, 2012.

BRASIL. Ministério do Meio Ambiente. Conselho Nacional do Meio Ambiente. Resolução CONAMA no 01, de 31 de janeiro de 1994. Regulamenta o art. 60 do Decreto no 750, de 10 de fev. de 1993 para o Estado de São Paulo. Brasília: DOU, 1994.

BERGALLO, H. G.; BERGALLO, A. C.; ROCHA, H. B; ROCHA, C. F. D.. Invasion by Artocarpus heterophyllus (Moraceae) in an island in the Atlantic Forest Biome, Brazil: distribution at the landscape level, density and need for control. Journal of Coastal Conservation, v.20, n.3, p.191-198, 2016. DOI: http://doi.org/10.1007/s11852-016-0429-9

SOS MATA ATLÂNTICA. Atlas of forest remnants of the Mata Atlântica period 2015: final report. São Paulo: The SOS, 2015.

HUSCH, B.; MILLER, C. L.; BEERS, T. E.. Forest mensuration. 3 ed. New York: J. Willey \& Sounds, 1982.

BRASIL. Ministério do Meio Ambiente. Instituto Brasileiro do Meio Ambiente e dos Recursos Naturais Renováveis. Flora. 2016.

INPE. Instituto Nacional de Pesquisas Espaciais. Sistema de Processamento de Informações Georeferenciadas. 2018.

LORENZI, H. J.. Brazilian trees: Book I. 5 ed. Nova Odessa: Publisher Plantarum, 2014.

LUCHIARI, A.; BARROSO, L. V.; SPILLER, A.B.; CARVALHO, L. S. DE; FERREIRA, T. A. Uso da Terra. In: FURLAN, S. A.. Diagnóstico Físico e socioambiental do Parque Riacho Grande no município de São Bernardo do Campo. São Paulo, 2012.

BRASIL. Ministério do Meio Ambiente. Biomes: Mata Atlântica, 2016.

RODRIGUES, V.A.; BUCCI, L. A; PINHEIRO, L. Z.; SIQUEIRA, H. E.; OLIVEIRA, P. J. D.. Biomas Brasileiros: conservação da biodiversidade, solo, floresta e água. Botucatu: FEPAF, 2017.
GOMES, A. S.; CLAVICO, E.. Propriedades físico-químicas da água. Rio de Janeiro: Departamento de Biologia Marinha/UFF, 2005.

SILVA, C. V. V.; TAVARES R.; FRANCISCO, C. F.. Estratificação Florística da Mata Santa Genoveva no Norte do Município de Presidente Prudente (SP). In: JORNADA FLUMINENSE DE BOTÂNICA, 31. Anais. Rio das Ostras: UENF, 2012.

SILVA, C. V. V.; SILVA, L. M. S.; TAVARES R.; SILVA, W. S. Utilização de Características Fitossociológicas e Bioindicadoras no Monitoramento Ambiental e Avaliação de Impacto nas Bacias do Rio Guandu-RJ. In: JORNADA FLUMINENSE DE BOTÂNICA, 32. Anais. Rio das Ostras: UENF, 2013.

SILVA, C. V. V.; ABREU, L. A. S.; LEAL, J. C.. Uso da Volumetria na Avaliação da Concentração de Carbono da APA GuanduJacatirão, Queimados-RJ. In: CONGRESSO NACIONAL DE MEIO AMBIENTE DE POÇOS DE CALDAS, 14. Anais. Poços de Caldas, 2017

SILVA, C.V.V.; TOMAS JUNIOR, O. A.; CARVALHO, L. O.; NOVAES, E. B.. Biomassa e Estimativa de Carbono Estocado em Ecossistema Florestal da Represa Billings-SP. In: Congresso Nacional do Meio Ambiente, 15. Anais. Poços de Caldas, 2018.

SILVA, C.V.V.; ABREU, L. A. S.; LEA, J. C.; LOUREIRO, A.; GROETARS, A.. Inventário Florístico da APA Guandu-Jacatirão o uso da Resolução CONAMA n.04, de maio de 1994 - RJ, para Análise de Parâmetros da Qualidade Ambiental. In: CONGRESSO NACIONAL DO MEIO AMBIENTE, 14. Anais. Poços de Caldas, 2017.

TAVARES R.; SILVA, C. V. V.; FRANCISCO, C. F.. Níveis de Ocorrência de Incêndios e Queimadas em Vegetação no Município de Itaguaí - RJ. In: Congresso Nacional do Meio Ambiente, 9. Anais. Poços de Caldas, 2012.

TAVARES R.; SILVA, C. V. V.; SILVA, L. M. S.; SILVA, W. S.. Comportamento estrutural da vegetação de um trecho da floresta atlântica da ilha grande, RJ. In: JORNADA FLUMINENSE DE BOTÂNICA, 32. Anais. Rio das Ostras: UENF, 2013.

A CBPC - Companhia Brasileira de Produção Científica (CNPJ: 11.221.422/0001-03) detém os direitos materiais desta publicação. Os direitos referem-se à publicação do trabalho em qualquer parte do mundo, incluindo os direitos às renovações, expansões e disseminações da contribuição, bem como outros direitos subsidiários. Todos os trabalhos publicados eletronicamente poderão posteriormente ser publicados em coletâneas impressas sob coordenação da Sustenere Publishing, da Companhia Brasileira de Produção Científica e seus parceiros autorizados. Os (as) autores (as) preservam os direitos autorais, mas não têm permissão para a publicação da contribuição em outro meio, impresso ou digital, em português ou em tradução. 